\title{
Implementasi Kontrol Model Prediksi Berbasis ANFIS Pada Mesin Penghasil Uap Air
}

\author{
Rangga Kurniawan Ladioktaviagusdi ${ }^{1}$, Raden Sumiharto ${ }^{2}$ \\ ${ }^{1}$ Prodi Elektronika dan Instrumentasi Jurusan Ilmu Komputer dan Elektronika, FMIPA UGM \\ ${ }^{2}$ Jurusan Ilmu Komputer dan Elektronika, FMIPA UGM \\ e-mail: *11 elmania91@gmail.com, ${ }^{2}$ r_sumiharto@mail.ugm.ac.id
}

\begin{abstract}
Abstrak
Mesin penghasil uap air mempunyai permasalahan pada parameter keluaran berupa dependent variabel, oleh karena itu diperlukan suatu cara untuk mendapatkan perilaku sistem dari mesin penghasil uap air yang direpresentasikan dengan model dari plant tersebut.Implementasi kontrol model prediksi pada penelitian ini direpresentasikan dengan menggunakan simulasi, sehingga objek yang dikontrol berupa mesin virtual penghasil uap air.Dalam penelitan ini digunakan perangkat lunak MATLAB sebagai mesin virtual penghasil uap air dan juga untuk melakukan komputasi ANFIS, sedangkan perangkat lunak LabVIEW digunakan sebagai representasi dari ruang kontrol.

Dari hasil penelitian, didapatkan parameter terbaik untuk masing-masing ANFIS yang dijadikan sebagai unit model pada kontrol model prediksi, yaitu dengan menggunakan historical data ke-4 yang berjumlah 800 data, dengan rasio presentase pembelajaran untuk training data dan checking data pada masing-masing ANFIS untuk setiap struktur model secara berurutan sebesar $90 \%$ dan 10\%, kecuali rasio presentase untuk ANFIS pada parameter aliran air secara berurutan sebesar 80\% dan 20\%. Hasil validasi RMSE (Root Mean Square Error) dengan melakukan pengujian terhadap 100 data, didapatkan nilai sebagai berikut: aliran air $=1.9941$, tekanan air=48.0236, aliran udara=604.0621, tekanan bahan bakar=0.7087, temperatur bahan bakar $=18.6594, O_{2}$ content $=0.9591$, tekanan uap air $=76.1557$, kualitas uap air $=3.9734$ dan aliran uap air $=264.9173$.
\end{abstract}

Kata kunci-Mesin penghasil uap air, kontrol model prediksi, pemodelan, ANFIS, MATLAB, LabVIEW

\begin{abstract}
Steam generator has problem such as dependent variable on the output parameters, therefore it is needed a way to get system behavior of steam generator which is represented by model of the plant. Implementation of the model predictive control in this research was represented by using simulation, so the object that was controlled was virtual steam generator. In this research was used MATLAB software as a virtual steam generator and also for computes ANFIS, whereas the LabVIEW software was used as a representation of control room.

From the research, it was found the best parameters for each ANFIS that was used as a model unit in the model predictive control, that was by using historical data $4^{\text {th }}$ as much as 800 datas, the percentage ratio of learning for training data and checking data on each ANFIS for each model structures sequentially by $90 \%$ and $10 \%$, except the percentage ratio for ANFIS on water flow parameter sequentially by $80 \%$ and $20 \%$. The results of validation RMSE (Root Mean Square Error) by testing for 100 datas, it was obtained values as follows: water flow $=1.9941$, water pressure $=48.0236$, air flow $=604.0621$, fuel gas pressure $=0.7087$, fuel gas temperature $=18.6594, O_{2}$ content $=0.9591$, steam pressure $=76.1557$, steam quality $=3.9734$ and steam flow $=264.9173$.
\end{abstract}

Keywords - Steam generator, model predictive control, modeling, ANFIS, MATLAB, LabVIEW

Received March $6^{\text {th }}$ 2014; Revised January $9^{\text {th }}$, 2015; Accepted April 15 ${ }^{\text {th }}, 2015$ 


\section{PENDAHULUAN}

$\mathrm{D}$ idalam implementasinya sistem kontrol proses memiliki banyak sekali permasalahan, seperti terdapatnya sifat interaksi pada suatu proses multivariable atau multiple-input multiple-output (MIMO), terjadinya kondisi long dead time, terdapatnya batasan dari suatu aktuator pada plant proses, hingga permasalahan mengenai optimasi dari suatu aksi kontrol terhadap proses yang terjadi. Pada banyak kasus, aksi kontrol konvensional sudah dapat menyelesaikan permasalahan-permasalahan yang ada pada suatu plant proses, seperti feedforward control diaplikasikan untuk menangani permasalahan gangguan pengukuran, override control diaplikasikan untuk menangani constraints dari suatu unit plant proses dan decoupling control digunakan untuk permasalahan sifat interaksi proses. Namun hal ini masih dinilai kurang, hal ini dikarenakan kemampuan masing-masing aksi kontrol konvensional tersebut hanya dapat menyelesasikan satu permasalahan dari setiap aksi kontrolnya. Bagaimanapun jika semua permasalahan kontrol tersebut terjadi secara bersamaan, maka sangat diperlukan pendekatan yang sistematis terhadap plant proses yang akan dikontrol.

Salah satu unit plant yang sering ditemui pada banyak industri energi maupun industri kimia adalah mesin penghasil uap air.Mesin penghasil uap air merupakan sebuah boiler yang digunakan untuk mengubah air menjadi uap air dengan kualitas bervariasi pada suatu tekanan discharge tertentu. Pada dasarnya mesin penghasil uap airmenggunakan parameter masukan fisis berupa air, udara dan bahan bakar, sedangkan parameter keluaran fisis yang dihasilkan berupa uap air.Parameter masukan dari mesin penghasil uap air perlu untuk dikendalikan agar diperoleh parameter keluaran yang sesuai dengan keadaan yang diperlukan ketika dipergunakan, sehingga mesin penghasil uap air dapat bekerja dengan optimal. Parameter keluaran dari mesin penghasil uap air berupa dependent variabel, maksudnya adalah besaran nilai yang dihasilkan merupakan hasil pengaruh dari interaksi setiap parameter masukan mesin penghasil uap air, maka diperlukan suatu cara untuk mendapatkan prilaku sistemdari mesin penghasil uap air.

Pemodelan mampu mengetahui prilaku sistem dari suatu plant, oleh karena itu dapat membantu dalam membuat desain kontrol baru.Model dari suatu sistem dapat membantu dalam mengidentifikasi parameter sistem, deteksi kesalahan dan optimasi.Salah satu jenis kontroler yang menggunakan model dari plant sebagai unit penyusun kontrolnya adalah kontrol model prediksi [1]. Pada plant yang besar dan kompleks, kontrol model prediksi tidak menjadi kontrol pengganti dari kontrol PID, namun sebagai kontrol tambahan [2].Dalam memperoleh model dari suatu plant, metode yang sering digunakan adalah metode pemodelan secara matematika, memperoleh sebuah model matematika untuk sebuah sistem sangatlah komplek dan memakan banyak waktu, karena pada penggunaannya sering membutuhkan linearization dan mengabaikan bebearapa parameter sistem [3].

\section{METODE PENELITIAN}

\subsection{Deskripsi Sistem Keseluruhan}

Sistem yang dirancang pada penelitian ini merupakan penelitian berkelanjutan, skema berwarna hijau pada Gambar 1 merupakan skema penelitian yang telah dilakukan sebelumnya pada saat melakukan kerja praktek di PT. Chevron Pacific Indonesia.Pada penelitian tersebut dilakukan analisa kinerja dari mesin penghasil uap air menggunakan kecerdasan buatan. Tahapan yang dilakukan dalam melakukan analisa kinerja dari mesin penghasil uap air, yaitu dengan melakukan pemodelan dari mesin penghasil uap air tersebut, yang bertujuan untuk mengidentifikasi terhadap proses yang terjadi [4]. Didalam melakukan pemetaan terhadap data masukan dan data keluaran, dilakukan pengambilan historical data yang berasal dari mesin penghasil uap air sebenarnya yang ditunjukan oleh huruf A pada Gambar 1 dengan menggunakan perangkat lunak XHQ, kemudian dilakukan pemodelan menggunakan ANFIS (Adaptive Neuro Fuzzy Inference System) yang ditunjukan oleh huruf B pada Gambar 1 dengan menggunakan perangkat lunak MATLAB. Hasil model kemudian dijadikan mesin virtual penghasil uap air

IJEIS Vol. 5, No. 1, April 2015 : 99 - 110 
untuk melakukan analisa kinerja mesin penghasil uap air yang ditunjukan oleh huruf $\mathrm{C}$ pada Gambar 1.

Skema penelitian yang dilakukan saat ini ditunjukan oleh skema berwarna biru pada Gambar 1, yaitu mengimplementasikan kontrol model prediksi pada mesin virtual penghasil uap air yang telah dibuat pada penelitian sebelumnya dalam bentuk simulasi. Didalam tahap pendesainan kontrol model prediksi, model diperoleh dengan mengguakan metode pemodelan secara black box, yaitu dengan menggunakan ruang lingkup AI (Artificial Intelligence) berupa ANFIS (Adaptive Neuro Fuzzy Inference System). Sehingga diperlukan historical data, historical data tersebut dijadikan sebagai training data pada tahap pemodelan menggunakan ANFIS.

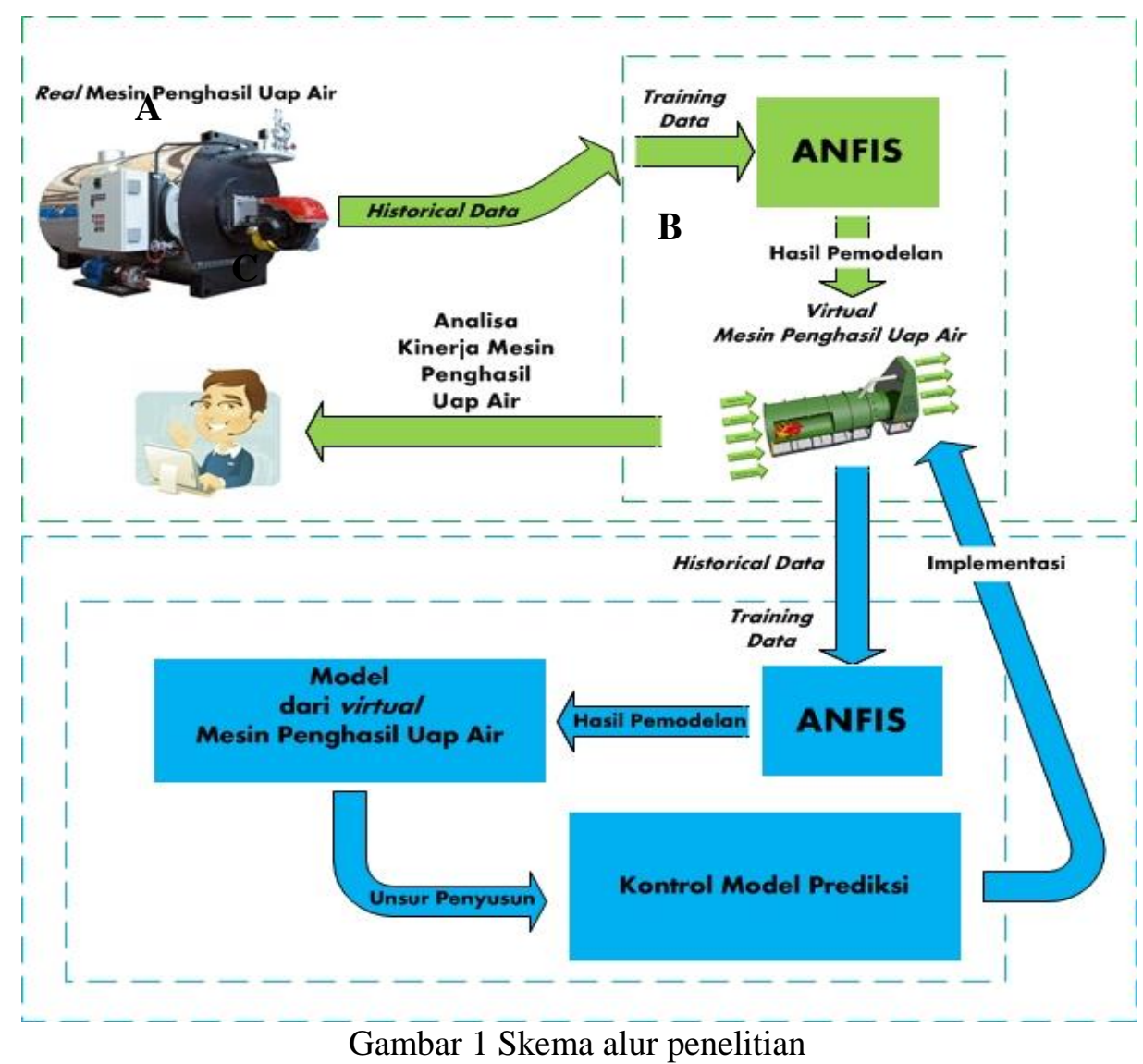

Historical datadidapat dari mesin virtual penghasil uap air yang telah dibuat pada penelitian sebelumnya. Parameter-parameter yang diambil sebagai historical data, yaitu parameter masukan dan parameter keluaran, untuk parameter masukan terdiri dari aliran air, tekanan air, aliran udara, tekanan bahan bakar dan temperatur bahan bakar, sedangkan untuk parameter keluaran terdiri dari $\mathrm{O}_{2}$ content, tekanan uap, kualitas uap dan aliran uap.

Kontrol model prediksi yang dirancang pada penelitian ini memiliki kemampuan sebagai berikut:

$>$ Mampu melakukan aksi kontrol terhadap parameter masukan dari mesin virtual penghasil uap air.

Mampu melakukan prediksi terhadap parameter keluaran mesin virtual penghasil uap air. Dari kemampuan kontrol yang telah dirancang diatas, maka kemampuan kontrol tersebut dapat saling melengkapi ketika kontrol model prediksi diimplementasikan pada mesin virtual penghasil uap air. Ketika kemampuan aksi kontrol masih belum mampu untuk menghasilkan keluran yang diinginkan, maka kemampuan aksi prediksi digunakan untuk melakukan nilai koreksi terhadap nilai parameter target yang diinginkan dengan melakukan simulasi off-line secara manual. 


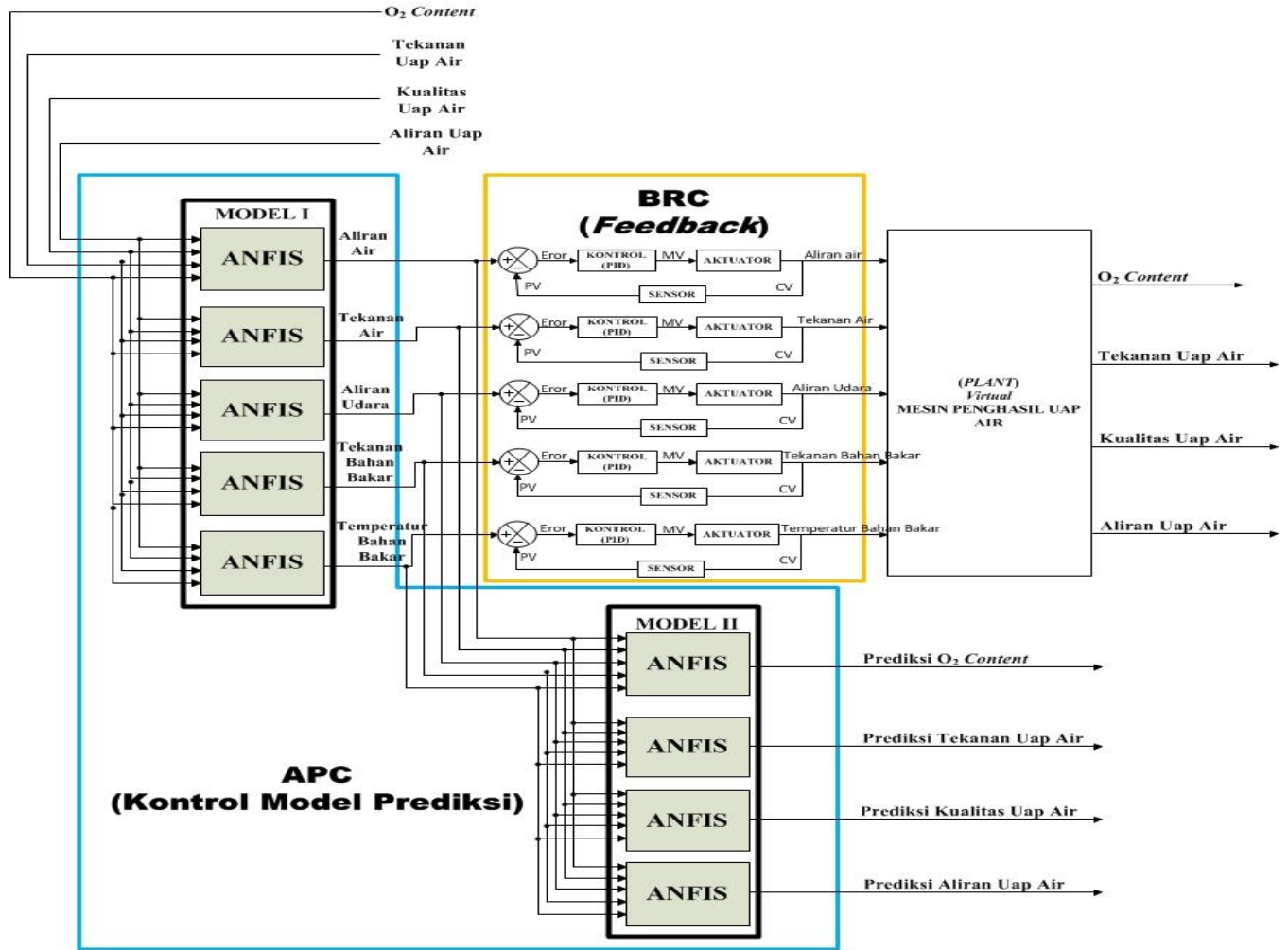

Gambar 2 Rancangan desain arsitektur kontrol keseluruhan

Rancangan kontrol model prediksi pada penelitian ini tidak menghilangkan kemampuan kontrol feedback dengan menggunakan PID yang berada pada layer BRC (Basic Regulatory Control). Namun kontrol model prediksi pada penelitian ini menjadi kontrol tambahan yang dapat menangani permasalahan yang ada pada plant proses secara keseluruhan. Gambar 2 merupakan rancangan desain arsitektur kontrol keseluruhan, skema kontrol yang berada didalam warna biru merupakan kontrol model prediksi yang menjadi bahasan pada penelitian ini. Kontrol model prediksi yang dirancang pada penelitian ini, terdiri dari 2 buah struktur model, struktur untuk model I terdiri dari 5 buah ANFIS dan struktur model II terdiri dari 4 buah ANFIS. Sedangkan skema kontrol yang berada didalam warna jingga direpresentasikan dengan kontrol feedback tidak masuk dalam bahasan penelitian ini.

\subsection{Implementasi Perangkat Keras}

Pada penelitian ini rancangan kontrol model prediksi diimplementasikan secara simulasi.Simulasi menggunakan 2 buah unit komputer, komputer pertama bertindak sebagai mesin virtual penghasil uap air dan juga melakukan komputasi ANFIS untuk mendapatkan model, sedangkan komputer kedua bertindak sebagai unit pengontrol plant pada control room.Kedua komputer saling terhubung dengan menggunakan komunikasi secara serial, yaitu memanfaatkan port USB yang ada pada kedua komputer. Gambar 3 menunjukan kedua komputer terhubung.

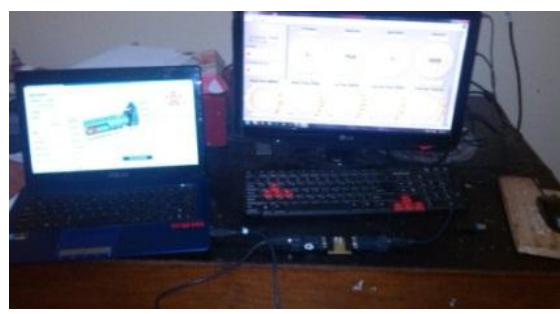

Gambar 3 Implementasi Perangkat keras 


\section{HASIL DAN PEMBAHASAN}

\subsection{Analisis Overfitting}

Analisis overfitting digunakan sebagai validasi hasil pemodelan dalam kemampuan generalisasi data. Keadaan overfitting pada suatu hasil model terjadi apabila fungsi model memaksa hasil model untuk sesuai dengan training data, namun mengabaikan kemampuan dalam melakukan prediksi data secara keseluruhan untuk pola data yang berbeda dari plant yang sama.

Dalam melakukan analisis overfitting, agar didapatkan parameter terbaik pada setiap ANFIS untuk masing-masing struktur model, dilakukan pengujian terhadap empat buah historical data.Pengujian dilakukan dengan memvariasikan besar presentase untuk training data dan checking data pada masing-masing historical data.

Historical data yang digunakan pada penelitian ini adalah sebagai berikut:

1. Historical data ke-1: Data berjumlah 229 data, data berasal dari data ke-2 yang telah dilakukan penghapusan terhadap data duplikat.

2. Historical data ke-2: Data berjumlah 500 data, data berasal dari mesin virtual penghasil uap air, pengambilan historical data dilakukan dengan mengubah parameter masukan mesin virtual penghasil uap air secara acak.

3. Historical data ke-3: Data berjumlah 478 data, data berasal dari data ke-4 yang telah dilakukan penghapusan terhadap data duplikat.

4. Historical data ke-4: Data berjumlah 800 data, data berasal dari mesin virtual penghasil uap air, pengambilan historical data dilakukan dengan mengubah parameter masukan mesin virtual penghasil uap air secara acak.

Analisis overfitting dilakukan pada setiap ANFIS untuk masing-masing struktur model I dan struktur model II, masing-masing struktur model tersebut bertindak sebagai unit kontrol dan unit prediksi. Pada penelitian ini dilakukan pencarian terhadap nilai RMSE checking dataseminimal mungkin, dengan cara menyertakan cheking data pada tahap pembelajaran dengan menggunakan ANFIS. Tujuan dilakukan pencarian terhadap nilai RMSE terkecil untuk checking error, yaitu agar ANFIS pada masing-masing struktur model mampu melakukan generalisasi data, dengan tetap mempertimbangkan nilai RMSE training data dari hasil pembelajaran. Sehingga ketika diimplementasikan sebagai kontrol model prediksi, kontrol model prediksi yang dibuat akan memiliki kinerja yang baik.

\subsubsection{Struktur model untuk kontrol (model I)}

Tabel 1, Tabel 2, Tabel 3, Tabel 4 dan Tabel 5 menunjukan hasil validasi masingmasing ANFIS pada struktur model I. Blok berwarna hijau pada setiap tabel tersebut, menunjukan selisih nilai terkecil antara nilai RMSE training data dengan nilai RMSE checking data, blok berwana kuning menunjukan nilai terkecil untuk RMSE checking data dan blok berwana biru menunjukan sifat keduannya. Tabel 1 menunjukan hasil validasi ANFIS untuk aliran air, berdasarkan Tabel 1, dapat dikatakan selisih nilai terkecil antara nilai RMSE training data dengan nilai RMSE checking data untuk historical data ke-1, historical data ke-2 dan historical data ke-4 berada pada presentase $20 \%$, sedangkan untuk historical data ke-3 berada pada presentase checking data sebesar $10 \%$. Nilai RMSE checking data terkecil pada Tabel 1 untuk historical data ke-1 dan historical data ke-2 berada pada presentase checking data sebesar $20 \%$, sedangkan nilai RMSE terkecil untuk historical data ke-3 dan historical data ke-4 berada pada presentase $50 \%$. 
Tabel 1 Hasil validasi ANFIS untuk aliran uap air

\begin{tabular}{|c|c|c|c|c|c|c|c|c|}
\hline \multirow{4}{*}{$\begin{array}{c}\text { ANFIS } \\
\text { Aliran Air }\end{array}$} & \multicolumn{8}{|c|}{ Jumlah Historical Data } \\
\hline & \multicolumn{2}{|c|}{229} & \multicolumn{2}{|c|}{500} & \multicolumn{2}{|c|}{478} & \multicolumn{2}{|c|}{800} \\
\hline & Training Data & Checking Data & Training Data & Checking Data & Training Data & Checking Data & Training Data & Checking Data \\
\hline & $90 \%$ & $10 \%$ & $90 \%$ & $10 \%$ & $90 \%$ & $10 \%$ & $90 \%$ & $10 \%$ \\
\hline Epoch & \multicolumn{2}{|c|}{86} & \multicolumn{2}{|r|}{11} & \multicolumn{2}{|c|}{72} & \multicolumn{2}{|c|}{304} \\
\hline \multirow[t]{3}{*}{ RMSE } & 0.049297 & 0.167662 & 0.051108 & 0.136705 & 0.390041 & 0.386194 & 1.87514 & 0.380116 \\
\hline & Training Data & Checking Data & Training Data & Checking Data & Training Data & Checking Data & Training Data & Checking Data \\
\hline & $80 \%$ & $20 \%$ & $80 \%$ & $20 \%$ & $80 \%$ & $20 \%$ & $80 \%$ & $20 \%$ \\
\hline Epoch & \multicolumn{2}{|c|}{16} & \multicolumn{2}{|c|}{92} & \multicolumn{2}{|c|}{61} & \multicolumn{2}{|c|}{225} \\
\hline \multirow[t]{3}{*}{ RMSE } & 0.117474 & 0.15767 & 0.121831 & 0.133745 & 1.660499 & 0.381511 & 1.80727 & 0.376087 \\
\hline & Training Data & Checking Data & Training Data & Checking Data & Training Data & Checking Data & Training Data & Checking Data \\
\hline & $\mathbf{7 0 \%}$ & $30 \%$ & $70 \%$ & $\mathbf{3 0} \%$ & $70 \%$ & $30 \%$ & $70 \%$ & $\mathbf{3 0} \%$ \\
\hline Epoch & \multicolumn{2}{|c|}{38} & \multicolumn{2}{|c|}{10} & \multicolumn{2}{|c|}{231} & \multicolumn{2}{|c|}{73} \\
\hline \multirow[t]{3}{*}{ RMSE } & 135.657583 & 0.77378 & 79.133753 & 0.786407 & 11.198612 & 0.369414 & 1.850435 & 0.367911 \\
\hline & Training Data & Checking Data & Training Data & Checking Data & \begin{tabular}{|l|} 
Training Data \\
\end{tabular} & Checking Data & Training Data & Checking Data \\
\hline & $60 \%$ & $40 \%$ & $60 \%$ & $40 \%$ & $60 \%$ & $40 \%$ & $60 \%$ & $40 \%$ \\
\hline Epoch & \multicolumn{2}{|r|}{3} & \multicolumn{2}{|c|}{24} & \multicolumn{2}{|r|}{52} & \multicolumn{2}{|r|}{90} \\
\hline \multirow[t]{3}{*}{ RMSE } & 35.307381 & 3.433641 & 99.368782 & 4.381767 & 5.934724 & \begin{tabular}{|c|}
0.355778 \\
\end{tabular} & 8.487787 & 0.361598 \\
\hline & Training Data & Checking Data & Training Data & Checking Data & Training Data & Checking Data & Training Data & Checking Data \\
\hline & $\mathbf{5 0 \%}$ & $\mathbf{5 0 \%}$ & $\mathbf{5 0 \%}$ & $\mathbf{5 0 \%}$ & $\mathbf{5 0 \%}$ & $\mathbf{5 0 \%}$ & $\mathbf{5 0 \%}$ & $\mathbf{5 0 \%}$ \\
\hline Epoch & \multicolumn{2}{|c|}{442} & \multicolumn{2}{|c|}{153} & \multicolumn{2}{|c|}{110} & \multicolumn{2}{|c|}{494} \\
\hline RMSE & 767.792665 & $\begin{array}{l}7.522446 \\
\end{array}$ & 392.275885 & $\begin{array}{ll} & 0.779441 \\
\end{array}$ & 6.972723 & 0.35163 & 4.64583 & \begin{tabular}{|l|l|} 
& 0.325385 \\
\end{tabular} \\
\hline
\end{tabular}

Tabel 2 Hasil validasi ANFIS untuk tekanan air

\begin{tabular}{|c|c|c|c|c|c|c|c|c|}
\hline \multirow{4}{*}{$\begin{array}{c}\text { ANFIS } \\
\text { Tekanan } \\
\text { Air }\end{array}$} & \multicolumn{8}{|c|}{ Jumlah Historical Data } \\
\hline & \multicolumn{2}{|c|}{229} & \multicolumn{2}{|c|}{500} & \multicolumn{2}{|c|}{478} & \multicolumn{2}{|c|}{800} \\
\hline & Training Data & Checking Data & Training Data & Checking Data & Training Data & Checking Data & Training Data & Checking Data \\
\hline & $90 \%$ & $10 \%$ & \begin{tabular}{|l|}
$90 \%$ \\
\end{tabular} & $10 \%$ & $90 \%$ & $10 \%$ & $90 \%$ & $10 \%$ \\
\hline Epoch & \multicolumn{2}{|c|}{14} & \multicolumn{2}{|c|}{36} & \multicolumn{2}{|c|}{174} & \multicolumn{2}{|c|}{403} \\
\hline \multirow[t]{3}{*}{ RMSE } & 8.277876 & 6.195829 & 9.313115 & 6.969917 & 29.565772 & 25.422158 & 31.070018 & 23.365728 \\
\hline & Training Data & Checking Data & Training Data & Checking Data & Training Data & Checking Data & Training Data & Checking Data \\
\hline & $80 \%$ & $20 \%$ & \begin{tabular}{|l|}
$80 \%$ \\
\end{tabular} & $20 \%$ & $\mathbf{8 0} \%$ & $\mathbf{2 0} \%$ & $80 \%$ & $20 \%$ \\
\hline Epoch & \multicolumn{2}{|c|}{106} & \multicolumn{2}{|c|}{16} & \multicolumn{2}{|c|}{174} & \multicolumn{2}{|c|}{491} \\
\hline \multirow[t]{3}{*}{ RMSE } & 6.048384 & 6.789913 & 7.432535 & 7.02621 & 31.652431 & 25.15796 & 98.196387 & 23.239351 \\
\hline & Training Data & Checking Data & Training Data & Checking Data & Training Data & Checking Data & Training Data & Checking Data \\
\hline & & $\mathbf{3 0 \%}$ & \begin{tabular}{|l|l}
$\mathbf{7 0 \%} \%$ \\
\end{tabular} & $30 \%$ & $70 \%$ & $\mathbf{3 0 \%}$ & $70 \%$ & $\mathbf{3 0} \%$ \\
\hline Epoch & \multicolumn{2}{|c|}{27} & \multicolumn{2}{|c|}{174} & \multicolumn{2}{|c|}{406} & \multicolumn{2}{|c|}{104} \\
\hline \multirow[t]{3}{*}{ RMSE } & 4639.510982 & 88.05603 & \begin{tabular}{|l|l}
907.957972 \\
\end{tabular} & 126.060103 & 42.39966 & 24.237299 & 75.415394 & 22.039675 \\
\hline & Training Data & Checking Data & Training Data & Checking Data & Training Data & Checking Data & Training Data & Checking Data \\
\hline & $60 \%$ & $40 \%$ & $60 \%$ & $40 \%$ & $60 \%$ & $\mathbf{4 0 \%}$ & $60 \%$ & $40 \%$ \\
\hline Epoch & \multicolumn{2}{|c|}{17} & \multicolumn{2}{|r|}{3} & \multicolumn{2}{|r|}{6} & \multicolumn{2}{|c|}{339} \\
\hline \multirow[t]{3}{*}{ RMSE } & 3075.230448 & 56.348089 & 6531.093101 & 213.09279 & 468.687719 & 23.796046 & 348.915976 & 20.609546 \\
\hline & Training Data & Checking Data & Training Data & Checking Data & Training Data & Checking Data & Training Data & Checking Data \\
\hline & $\mathbf{5 0} \%$ & \begin{tabular}{|l|}
$\mathbf{5 0} \%$ \\
\end{tabular} & \begin{tabular}{|l|}
$\mathbf{5 0 \%}$ \\
\end{tabular} & $\mathbf{5 0 \%}$ & \begin{tabular}{|l|}
$\mathbf{5 0} \%$ \\
\end{tabular} & $\mathbf{5 0 \%}$ & \begin{tabular}{|l|}
$\mathbf{5 0} \%$ \\
\end{tabular} & $\mathbf{5 0 \%}$ \\
\hline Epoch & \multicolumn{2}{|c|}{100} & \multicolumn{2}{|c|}{61} & \multicolumn{2}{|c|}{498} & \multicolumn{2}{|c|}{458} \\
\hline & 6826.132847 & 26.562529 & 20126.4036 & 905087 & 184.851523 & 508027 & 723.421482 & 1667 \\
\hline
\end{tabular}

Tabel 3 Hasil validasi ANFIS untuk aliran udara

\begin{tabular}{|c|c|c|c|c|c|c|c|c|}
\hline \multirow{4}{*}{$\begin{array}{l}\text { ANFIS } \\
\text { Aliran } \\
\text { Udara }\end{array}$} & \multicolumn{8}{|c|}{ Jumlah Historical Data } \\
\hline & \multicolumn{2}{|c|}{229} & \multicolumn{2}{|r|}{500} & \multicolumn{2}{|c|}{478} & \multicolumn{2}{|c|}{800} \\
\hline & Training Data & Checking Data & Training Data & Checking Data & Training Data & Checking Data & Training Data & Checking Data \\
\hline & $90 \%$ & $10 \%$ & $90 \%$ & $10 \%$ & $90 \%$ & $10 \%$ & $90 \%$ & $10 \%$ \\
\hline Epoch & \multicolumn{2}{|c|}{103} & \multicolumn{2}{|c|}{272} & \multicolumn{2}{|c|}{107} & \multicolumn{2}{|c|}{210} \\
\hline \multirow[t]{3}{*}{ RMSE } & 24.255112 & 240.869668 & 33.809132 & 79.560015 & 852.668186 & 264.296705 & 462.639441 & 249.340063 \\
\hline & Training Data & Checking Data & Training Data & Checking Data & Training Data & Checking Data & Training Data & Checking Data \\
\hline & $80 \%$ & $20 \%$ & $80 \%$ & $20 \%$ & $80 \%$ & $20 \%$ & $80 \%$ & $20 \%$ \\
\hline Epoch & \multicolumn{2}{|c|}{10} & \multicolumn{2}{|c|}{332} & \multicolumn{2}{|c|}{282} & \multicolumn{2}{|c|}{259} \\
\hline \multirow[t]{3}{*}{ RMSE } & 19.643779 & 153.495031 & 26.487952 & 77.980306 & 3693.977852 & 263.131011 & 1816.001538 & 247.245591 \\
\hline & Training Data & Checking Data & Training Data & Checking Data & Training Data & Checking Data & Training Data & Checking Data \\
\hline & $70 \%$ & $30 \%$ & $70 \%$ & $30 \%$ & $70 \%$ & $30 \%$ & $70 \%$ & $30 \%$ \\
\hline Epoch & \multicolumn{2}{|c|}{274} & \multicolumn{2}{|c|}{138} & \multicolumn{2}{|c|}{6} & \multicolumn{2}{|c|}{35} \\
\hline \multirow[t]{3}{*}{ RMSE } & 7767.684433 & 2162.711491 & 5401.517416 & 1279.135721 & 3936.919582 & 258.883905 & 3428.795021 & 241.919566 \\
\hline & Training Data & Checking Data & Training Data & Checking Data & Training Data & Checking Data & Training Data & Checking Data \\
\hline & $\%$ & $40 \%$ & $60 \%$ & $40 \%$ & $60 \%$ & $40 \%$ & $60 \%$ & $40 \%$ \\
\hline Epoch & \multicolumn{2}{|c|}{340} & \multicolumn{2}{|c|}{423} & \multicolumn{2}{|r|}{4} & \multicolumn{2}{|c|}{233} \\
\hline \multirow[t]{3}{*}{ RMSE } & 63337.67834 & 669.571975 & 219513.7411 & 631.996578 & 2911.108855 & 249.675159 & 2166.733794 & 230.990872 \\
\hline & Training Data & Checking Data & Training Data & Checking Data & Training Data & Checking Data & Training Data & Checking Data \\
\hline & & & & & \begin{tabular}{|l|}
$\mathbf{5 0} \%$ \\
\end{tabular} & $\mathbf{5 0} \%$ & $\mathbf{5 0 \%}$ & $\mathbf{5 0} \%$ \\
\hline Epoch & \multicolumn{2}{|c|}{13} & \multicolumn{2}{|r|}{1} & & \multicolumn{2}{|c|}{417} \\
\hline RMSE & 355927.485 & 3669.844655 & 409866.892 & \begin{tabular}{|l}
5399.069237 \\
\end{tabular} & 4384.65231 & 239.40855 & 2931.897912 & 200.244661 \\
\hline
\end{tabular}

IJEIS Vol. 5, No. 1, April 2015 : 99 - 110 
Tabel 4 Hasil validasi ANFIS untuk tekanan bahan bakar

\begin{tabular}{|c|c|c|c|c|c|c|c|c|}
\hline ANFIS & \multicolumn{8}{|c|}{ Jumlah Historical Data } \\
\hline Tekanan & \multicolumn{2}{|c|}{229} & \multicolumn{2}{|r|}{500} & \multicolumn{2}{|c|}{478} & \multicolumn{2}{|c|}{800} \\
\hline Bahan & \begin{tabular}{|l|} 
Training Data \\
\end{tabular} & Checking Data & Training Data & Checking Data & Training Data & Checking Data & Training Data & Checking Data \\
\hline Bakar & $90 \%$ & $10 \%$ & $90 \%$ & $10 \%$ & $90 \%$ & $10 \%$ & $90 \%$ & $10 \%$ \\
\hline Epoch & \multicolumn{2}{|c|}{34} & \multicolumn{2}{|c|}{419} & \multicolumn{2}{|c|}{62} & \\
\hline \multirow[t]{3}{*}{ RMSE } & 0.009842 & 0.22892 & 0.016543 & $\begin{array}{ll}0.096299 \\
\end{array}$ & 0.168814 & 0.154679 & 0.192226 & 0.144475 \\
\hline & Training Data & Checking Data & Training Data & \begin{tabular}{|l} 
Checking Data \\
\end{tabular} & Training Data & Checking Data & Training Data & Checking Date \\
\hline & $80 \%$ & $20 \%$ & & $20 \%$ & $\mathbf{8 0 \%}$ & $20 \%$ & $30 \%$ & \\
\hline Epoch & \multicolumn{2}{|c|}{40} & \multicolumn{2}{|c|}{85} & \multicolumn{2}{|c|}{317} & \multicolumn{2}{|c|}{17} \\
\hline \multirow[t]{3}{*}{ RMSE } & 0.131771 & 0.179583 & 0.106284 & 0.093078 & 0.202544 & 0.149774 & 2.011646 & 0.142463 \\
\hline & Training Data & Checking Data & Training Data & \begin{tabular}{|l|} 
Checking Data \\
\end{tabular} & Training Data & Checking Data & Training Data & Checking Data \\
\hline & $70 \%$ & $30 \%$ & $70 \%$ & $30 \%$ & $70 \%$ & $30 \%$ & $70 \%$ & $30 \%$ \\
\hline Epoch & \multicolumn{2}{|r|}{4} & \multicolumn{2}{|c|}{223} & \multicolumn{2}{|c|}{21} & \multicolumn{2}{|c|}{18} \\
\hline \multirow[t]{3}{*}{ RMSE } & 18.110509 & 0.46069 & 18.891008 & 0.148268 & 2.169302 & 0.152658 & 3.021852 & 0.141607 \\
\hline & Training Data & Checking Data & Training Data & \begin{tabular}{|l|} 
Checking Data \\
\end{tabular} & Training Data & Checking Data & Training Data & Checking Data \\
\hline & & & & & $60 \%$ & $40 \%$ & $60 \%$ & $40 \%$ \\
\hline Epoch & \multicolumn{2}{|c|}{337} & \multicolumn{2}{|c|}{449} & \multicolumn{2}{|c|}{321} & \multicolumn{2}{|c|}{250} \\
\hline \multirow[t]{3}{*}{ RMSE } & 36.41056 & $\begin{array}{l}0.727929 \\
\end{array}$ & 27.238293 & $\begin{array}{l}0.850467 \\
\end{array}$ & 1.44086 & 0.149819 & 0.700049 & \begin{tabular}{|l}
0.123899 \\
\end{tabular} \\
\hline & Training Data & Checking Data & Training Data & \begin{tabular}{|l} 
Checking Data \\
\end{tabular} & Training Data & Checking Data & Training Data & Checking Dat \\
\hline & $\mathbf{5 0 \%}$ & $\mathbf{5 0 \%}$ & $\mathbf{5 0 \%}$ & $\mathbf{5 0 \%}$ & $\mathbf{5 0 \%}$ & $\mathbf{5 0 \%}$ & $\mathbf{5 0 \%}$ & $50 \%$ \\
\hline Epoch & \multicolumn{2}{|c|}{73} & \multicolumn{2}{|r|}{217} & \multicolumn{2}{|c|}{437} & \multicolumn{2}{|c|}{27} \\
\hline RMSE & 222.957424 & 0.129973 & 231.871168 & 0.618844 & 0.811301 & 0.137822 & 2.520898 & 0.123352 \\
\hline
\end{tabular}

Tabel 5 Hasil validasi ANFIS untuk temperatur bahan bakar

\begin{tabular}{|c|c|c|c|c|c|c|c|c|}
\hline ANFIS & \multicolumn{8}{|c|}{ Jumlah Historical Data } \\
\hline Temperatur & \multicolumn{2}{|c|}{229} & \multicolumn{2}{|c|}{\begin{tabular}{|l|l|}
500 &
\end{tabular}} & \multicolumn{2}{|c|}{\begin{tabular}{|r|}
478 \\
\end{tabular}} & \multicolumn{2}{|c|}{800} \\
\hline Bahan & Training Data & Checking Data & Training Data & Checking Data & Training Data & Checking Data & Training Data & Checking Data \\
\hline Bakar & $90 \%$ & $10 \%$ & $90 \%$ & $10 \%$ & $90 \%$ & $10 \%$ & $90 \%$ & $10 \%$ \\
\hline Epoch & \multicolumn{2}{|c|}{130} & \multicolumn{2}{|c|}{12} & \multicolumn{2}{|c|}{144} & \multicolumn{2}{|c|}{255} \\
\hline \multirow[t]{3}{*}{ RMSE } & 14.942736 & 11.85668 & 14.352226 & 11.780321 & 17.566986 & 11.690967 & 17.62988 & 11.283791 \\
\hline & Training Data & Checking Data & Training Data & Checking Data & Training Data & Checking Data & Training Data & Checking Data \\
\hline & $80 \%$ & $20 \%$ & $80 \%$ & $20 \%$ & $80 \%$ & $20 \%$ & $80 \%$ & $20 \%$ \\
\hline Epoch & \multicolumn{2}{|c|}{51} & \multicolumn{2}{|c|}{5} & \multicolumn{2}{|c|}{109} & \multicolumn{2}{|c|}{320} \\
\hline \multirow[t]{3}{*}{ RMSE } & 12.403717 & 8.738039 & 13.947731 & 5.31333 & 32.167278 & 11.80351 & 47.605277 & 11.355452 \\
\hline & Training Data & Checking Data & Training Data & Checking Data & Training Data & Checking Data & Training Data & Checking Data \\
\hline & $70 \%$ & $30 \%$ & $70 \%$ & $30 \%$ & \begin{tabular}{|l|}
$70 \%$ \\
\end{tabular} & $30 \%$ & $70 \%$ & $30 \%$ \\
\hline Epoch & \multicolumn{2}{|r|}{3} & \multicolumn{2}{|c|}{34} & \multicolumn{2}{|c|}{285} & \multicolumn{2}{|c|}{157} \\
\hline \multirow[t]{3}{*}{ RMSE } & 670.845713 & 22.926872 & 216.771482 & 16.767263 & 61.552246 & 11.449459 & 162.192237 & 11.28127 \\
\hline & Training Data & Checking Data & Training Data & Checking Data & Training Data & Checking Data & Training Data & Checking Data \\
\hline & $60 \%$ & $40 \%$ & $60 \%$ & $40 \%$ & $60 \%$ & $40 \%$ & $60 \%$ & $40 \%$ \\
\hline Epoch & \multicolumn{2}{|r|}{8} & \multicolumn{2}{|c|}{114} & \multicolumn{2}{|c|}{96} & \multicolumn{2}{|c|}{34} \\
\hline \multirow[t]{3}{*}{ RMSE } & 1056.427567 & 41.137719 & 1960.055727 & 20.651775 & 38.601829 & 11.661189 & 441.594041 & 11.154639 \\
\hline & Training Data & Checking Data & Training Data & Checking Data & Training Data & Checking Data & Training Data & Checking Data \\
\hline & $\mathbf{5 0 \%}$ & $\mathbf{5 0 \%}$ & $\mathbf{5 0 \%}$ & $\mathbf{5 0 \%}$ & $\mathbf{5 0 \%}$ & $\mathbf{5 0 \%}$ & $50 \%$ & $\mathbf{5 0 \%}$ \\
\hline Epoch & \multicolumn{2}{|c|}{37} & \multicolumn{2}{|c|}{35} & \multicolumn{2}{|c|}{27} & \multicolumn{2}{|c|}{244} \\
\hline RMSE & 10766.81289 & 217.246325 & 23894.62219 & 120.29291 & 301.269153 & 11.453513 & 345.909356 & 9.776612 \\
\hline
\end{tabular}

Pada Tabel 2 menunjukan hasil validasi ANFIS untuk tekanan air. Selisih nilai terkecil antara nilai RMSE training data dengan nilai RMSE checking data untuk historicaldata ke-1 dan historical data ke-2 berada pada presentase 20\%, sedangkan untuk historical data ke-3 dan historical data ke-4 berada pada presentase checking data sebesar 10\%. Nilai RMSE checking data terkecil pada Tabel 2 untuk historical data ke-1 dan historical data ke-2 berada pada presentase checking data sebesar 10\%, sedangkan untuk historical data ke-3 dan historical data ke-4 berada pada presentase checking data sebesar 50\%.Tabel 3 menunjukan hasil validasi ANFIS untuk aliran udara.Selisih nilai terkecil antara nilai RMSE training data dengan nilai RMSE checking data untuk historical data ke-1 berada pada presentase checking data sebesar 
$20 \%$.Sedangkan untuk historical data ke-2 hingga historical data ke-4 berada pada presentase checking data sebesar 10\%.Nilai RMSE checking data terkecil untuk historical data ke-1 dan historical data ke-2 berada pada presentase checking data sebesar 20\%, sedangkan untuk historical data ke-3 dan historical data ke-4 berada pada presentase checking data sebesar $50 \%$.

Tabel 4 menunjukan hasil validasi ANFIS untuk tekanan bahan bakar. Presentase checking data sebesar $20 \%$ pada historical data ke-2 memiliki selisih nilai terkecil antara nilai RMSE training data dengan nilai RMSE checking data dan sekaligus memiliki nilai RMSE checking data terkecil. Kemudian untuk selisih nilai terkecil antara nilai RMSE training data dengan nilai RMSE checking data untuk historical data ke-1 berada pada presentase checking data sebesar $20 \%$, sedangkan untuk historical data ke-3 dan historical data ke-4, nilai selisih terkecil berada pada presentase checking data sebesar 10\%. Nilai RMSE checking data terkecil untuk historical data ke-1, historical data ke-3 dan historical data ke-4 berada pada presentase checking data sebesar 50\%.Tabel 5 menunjukan hasil validasi ANFIS untuk temperature bahan bakar. Selisih nilai terkecil antara nilai RMSE training data dengan nilai RMSE checking data untuk masingmasing historical data berada pada presentase checking data sebesar $10 \%$, sedangakn nilai RMSE checking data terkecil untuk historical data ke-1 dan historical data ke-2 berada pada presentase checking data sebesar $20 \%$, kemudian untuk historical data ke-3 dan historical data ke-4 berada masing-masing pada presentase checking data sebesar 30\% dan 50\%.

\subsubsection{Struktur model untuk kontrol (model II)}

Tabel 6, Tabel 7, Tabel 8 dan Tabel 9 menunjukan hasil validasi masing-masing ANFIS pada struktur model II. Tabel 6 menunjukan hasil validasi ANFIS untuk $\mathrm{O}_{2}$ content. Selisih nilai terkecil antara nilai RMSE training data dengan nilai RMSE checking data untuk keseluruhan historical data berada pada presentase checking data sebesar 10\%.Nilai RMSE checking data terkecil untuk historical data ke-1 berada pada presentase checking data sebesar $40 \%$, sedangkan untuk historical data ke-2, historical data ke-3 dan historical data ke-4 berada pada presentase checking data sebesar 50\%.

Tabel 6 Hasil validasi ANFIS untuk $\mathrm{O}_{2}$ content

\begin{tabular}{|c|c|c|c|c|c|c|c|c|}
\hline \multirow{4}{*}{$\begin{array}{c}\text { ANFIS } \\
02 \\
\text { Content }\end{array}$} & \multicolumn{8}{|c|}{ Jumlah Historical Data } \\
\hline & \multicolumn{2}{|c|}{229} & \multicolumn{2}{|c|}{\begin{tabular}{|c|}
500 \\
\end{tabular}} & \multicolumn{2}{|c|}{478} & \multicolumn{2}{|c|}{$\begin{array}{r}800 \\
\end{array}$} \\
\hline & Training Data & Checking Data & Training Data & Checking Data & Training Data & Checking Data & Training Data & Checking Data \\
\hline & $90 \%$ & $10 \%$ & $90 \%$ & $10 \%$ & $90 \%$ & $10 \%$ & $90 \%$ & $10 \%$ \\
\hline Epoch & \multicolumn{2}{|r|}{397} & \multicolumn{2}{|r|}{30} & \multicolumn{2}{|c|}{488} & \multicolumn{2}{|c|}{157} \\
\hline \multirow[t]{3}{*}{ RMSE } & 0.011451 & 0.046142 & 0.008364 & 0.032890 & 0.542974 & 0.191441 & 0.680863 & 0.171279 \\
\hline & Training Data & Checking Data & Training Data & Checking Data & Training Data & Checking Data & Training Data & Checking Data \\
\hline & $80 \%$ & $20 \%$ & $\mathbf{8 0 \%}$ & $20 \%$ & $\mathbf{8 0 \%}$ & $20 \%$ & $\mathbf{8 0 \%}$ & $20 \%$ \\
\hline Epoch & \multicolumn{2}{|c|}{69} & \multicolumn{2}{|c|}{147} & \multicolumn{2}{|r|}{10} & \multicolumn{2}{|c|}{132} \\
\hline \multirow[t]{3}{*}{ RMSE } & 1.11918 & 0.048236 & 1.878727 & 0.041208 & 0.66809 & 0.228996 & 1.00057 & 0.123416 \\
\hline & Training Data & Checking Data & Training Data & Checking Data & Training Data & Checking Data & Training Data & Checking Data \\
\hline & $70 \%$ & $30 \%$ & $70 \%$ & $\mathbf{3 0 \%}$ & $70 \%$ & $\mathbf{3 0 \%}$ & $70 \%$ & $30 \%$ \\
\hline Epoch & \multicolumn{2}{|c|}{74} & \multicolumn{2}{|r|}{5} & \multicolumn{2}{|c|}{460} & \multicolumn{2}{|r|}{375} \\
\hline \multirow[t]{3}{*}{ RMSE } & 12.484112 & \begin{tabular}{|l|l|}
0.078635 \\
\end{tabular} & 23.016751 & 0.034023 & 0.96043 & \begin{tabular}{|l|}
0.135899 \\
\end{tabular} & \begin{tabular}{|l|}
1.404869 \\
\end{tabular} & 0.095511 \\
\hline & Training Data & Checking Data & Training Data & Checking Data & Training Data & Checking Data & Training Data & Checking Data \\
\hline & $60 \%$ & $40 \%$ & $60 \%$ & $40 \%$ & $\mathbf{6 0 \%}$ & $\mathbf{4 0 \%}$ & \begin{tabular}{|l|}
$60 \%$ \\
\end{tabular} & $40 \%$ \\
\hline Epoch & \multicolumn{2}{|r|}{7} & \multicolumn{2}{|c|}{465} & \multicolumn{2}{|c|}{485} & \multicolumn{2}{|c|}{460} \\
\hline \multirow[t]{3}{*}{ RMSE } & 38.482263 & 0.011768 & 62.210384 & 0.022704 & 1.111464 & 0.102563 & 1.439591 & 0.072877 \\
\hline & Training Data & Checking Data & Training Data & Checking Data & Training Data & Checking Data & Training Data & Checking Data \\
\hline & $\mathbf{5 0 \%}$ & $50 \%$ & $\mathbf{5 0 \%}$ & $50 \%$ & $\mathbf{5 0 \%}$ & $50 \%$ & $\mathbf{5 0 \%}$ & $\mathbf{5 0 \%}$ \\
\hline Epoch & \multicolumn{2}{|r|}{88} & \multicolumn{2}{|r|}{222} & \multicolumn{2}{|r|}{373} & \multicolumn{2}{|c|}{1} \\
\hline RMSE & 11.234639 & 0.013219 & 12.61775 & $\begin{array}{l}0.017237 \\
\end{array}$ & 1.152083 & 0.088914 & 1.193406 & 0.064376 \\
\hline
\end{tabular}

IJEIS Vol. 5, No. 1, April 2015 : 99 - 110 
Tabel 7 Hasil validasi ANFIS untuk tekanan uap air

\begin{tabular}{|c|c|c|c|c|c|c|c|c|}
\hline \multirow{4}{*}{$\begin{array}{c}\text { ANFIS } \\
\text { Tekanan } \\
\text { Uap Air }\end{array}$} & \multicolumn{8}{|c|}{ Jumlah Historical Data } \\
\hline & \multicolumn{2}{|c|}{229} & \multicolumn{2}{|c|}{500} & \multicolumn{2}{|c|}{\begin{tabular}{|r|}
478 \\
\end{tabular}} & \multicolumn{2}{|c|}{800} \\
\hline & Training Data & Checking Data & Training Data & \begin{tabular}{|l|} 
a Checking Data \\
\end{tabular} & Training Data & Checking Data & Training Data & Checking Data \\
\hline & $90 \%$ & $10 \%$ & $90 \%$ & $10 \%$ & $90 \%$ & $10 \%$ & $90 \%$ & $10 \%$ \\
\hline Epoch & \multicolumn{2}{|c|}{21} & \multicolumn{2}{|r|}{19} & \multicolumn{2}{|c|}{19} & \multicolumn{2}{|r|}{5} \\
\hline \multirow[t]{3}{*}{ RMSE } & 12.803519 & 9.294116 & 1.768276 & 5.872019 & 55.860265 & \begin{tabular}{|l}
20.261541 \\
\end{tabular} & 58.660537 & 19.438676 \\
\hline & Training Data & Checking Data & Training Data & $\begin{array}{l}\text { a Checking Data } \\
\end{array}$ & Training Data & Checking Data & Training Data & Checking Data \\
\hline & $\mathbf{8 0 \%}$ & $20 \%$ & \begin{tabular}{|l|}
$\mathbf{8 0} \%$ \\
\end{tabular} & $20 \%$ & $80 \%$ & $20 \%$ & $\mathbf{8 0 \%}$ & $\mathbf{2 0 \%}$ \\
\hline Epoch & \multicolumn{2}{|c|}{162} & \multicolumn{2}{|r|}{34} & \multicolumn{2}{|r|}{4} & \multicolumn{2}{|r|}{3} \\
\hline \multirow[t]{3}{*}{ RMSE } & 160.739627 & 8.094895 & 681.934991 & 7.380944 & 52.849658 & 19.621069 & 65.607905 & 17.708109 \\
\hline & Training Data & Checking Data & Training Data & a Checking Data & Training Data & Checking Data & Training Data & Checking Data \\
\hline & $70 \%$ & $\mathbf{3 0 \%}$ & $70 \%$ & $\mathbf{3 0 \%}$ & $\mathbf{7 0 \%}$ & $\mathbf{3 0} \%$ & \begin{tabular}{|l|}
$70 \%$ \\
\end{tabular} & $30 \%$ \\
\hline Epoch & \multicolumn{2}{|c|}{55} & \multicolumn{2}{|r|}{15} & \multicolumn{2}{|r|}{3} & \multicolumn{2}{|r|}{3} \\
\hline \multirow[t]{3}{*}{ RMSE } & 1156.455833 & 15.569662 & 2171.546476 & 6.585264 & 63.764077 & 20.138969 & 91.336645 & 15.123412 \\
\hline & Training Data & Checking Data & Training Data & Checking Data & Training Data & Checking Data & Training Data & Checking Data \\
\hline & $\mathbf{6 0 \%}$ & $40 \%$ & $\mathbf{6 0 \%}$ & $40 \%$ & $\mathbf{6 0 \%}$ & $40 \%$ & $\mathbf{6 0 \%}$ & $40 \%$ \\
\hline Epoch & \multicolumn{2}{|c|}{85} & \multicolumn{2}{|r|}{15} & \multicolumn{2}{|c|}{486} & \multicolumn{2}{|c|}{126} \\
\hline \multirow[t]{3}{*}{ RMSE } & 1262.687266 & 3.742137 & 3105.209058 & 4.454896 & 56.632129 & 10.039061 & 75.624557 & 10.138908 \\
\hline & Training Data & Checking Data & Training Data & a Checking Data & Training Data & Checking Data & Training Data & Checking Data \\
\hline & $\mathbf{5 0} \%$ & $\mathbf{5 0} \%$ & $\mathbf{5 0} \%$ & \begin{tabular}{|l}
$\mathbf{5 0} \%$ \\
\end{tabular} & $\mathbf{5 0} \%$ & \begin{tabular}{|l}
$\mathbf{5 0} \%$ \\
\end{tabular} & $\mathbf{5 0 \%}$ & $\mathbf{5 0 \%}$ \\
\hline Epoch & \multicolumn{2}{|c|}{127} & \multicolumn{2}{|r|}{153} & \multicolumn{2}{|c|}{228} & \multicolumn{2}{|r|}{9} \\
\hline RMSE & 1443.995519 & 3.067146 & 1310.715298 & 3.432444 & 57.144954 & 9.256998 & 100.540794 & 11.122608 \\
\hline
\end{tabular}

Tabel 8 Hasil validasi ANFIS untuk kualitas uap air

\begin{tabular}{|c|c|c|c|c|c|c|c|c|}
\hline \multirow{4}{*}{$\begin{array}{c}\text { ANFIS } \\
\text { Kualitas } \\
\text { Uap Air }\end{array}$} & \multicolumn{8}{|c|}{ Jumlah Historical Data } \\
\hline & \multicolumn{2}{|c|}{229} & \multicolumn{2}{|c|}{500} & \multicolumn{2}{|c|}{478} & \multicolumn{2}{|c|}{800} \\
\hline & Training Data & Checking Data & Training Data & Checking Data & Training Data & Checking Data & Training Data & Checking Data \\
\hline & $90 \%$ & $10 \%$ & $90 \%$ & $10 \%$ & $90 \%$ & $10 \%$ & $90 \%$ & $10 \%$ \\
\hline Epoch & \multicolumn{2}{|c|}{33} & \multicolumn{2}{|c|}{125} & \multicolumn{2}{|c|}{195} & \multicolumn{2}{|c|}{330} \\
\hline \multirow[t]{3}{*}{ RMSE } & 5.182192 & 0.950188 & 0.089273 & 0.545437 & 1.286896 & 0.86679 & 1.875531 & 0.759787 \\
\hline & Training Data & Checking Data & Training Data & Checking Data & Training Data & Checking Data & Training Data & Checking Data \\
\hline & $80 \%$ & $20 \%$ & $80 \%$ & $20 \%$ & $80 \%$ & $\mathbf{2 0 \%}$ & $80 \%$ & $20 \%$ \\
\hline Epoch & \multicolumn{2}{|c|}{81} & \multicolumn{2}{|c|}{273} & \multicolumn{2}{|c|}{292} & \multicolumn{2}{|c|}{234} \\
\hline \multirow{3}{*}{ RMSE } & 7.40247 & 0.371582 & 9.941742 & 0.659375 & 2.063736 & 0.791154 & 2.357593 & $\begin{array}{l}0.679922 \\
\end{array}$ \\
\hline & Training Data & Checking Data & Training Data & Checking Data & Training Data & Checking Data & Training Data & Checking Data \\
\hline & $70 \%$ & $30 \%$ & $\mathbf{7 0 \%}$ & $\mathbf{3 0} \%$ & $70 \%$ & $30 \%$ & $70 \%$ & $\mathbf{3 0 \%}$ \\
\hline Epoch & \multicolumn{2}{|c|}{25} & \multicolumn{2}{|c|}{21} & \multicolumn{2}{|c|}{238} & \multicolumn{2}{|c|}{293} \\
\hline \multirow[t]{3}{*}{ RMSE } & 114.006249 & 0.308642 & 118.856547 & 0.292546 & 1.942466 & 0.777817 & 3.230865 & 0.645751 \\
\hline & Training Data & Checking Data & Training Data & Checking Data & Training Data & Checking Data & Training Data & Checking Data \\
\hline & $\mathbf{6 0 \%}$ & $40 \%$ & $60 \%$ & $40 \%$ & $60 \%$ & $40 \%$ & $60 \%$ & $40 \%$ \\
\hline Epoch & \multicolumn{2}{|c|}{4} & \multicolumn{2}{|c|}{32} & \multicolumn{2}{|c|}{327} & \multicolumn{2}{|c|}{490} \\
\hline \multirow[t]{3}{*}{ RMSE } & 276.130762 & 0.8662 & 497.254162 & 0.652002 & 3.160738 & 0.679327 & 4.11405 & 0.578563 \\
\hline & Training Data & Checking Data & Training Data & Checking Data & Training Data & Checking Data & Training Data & Checking Data \\
\hline & $\mathbf{5 0} \%$ & $\mathbf{5 0 \%}$ & $\mathbf{5 0} \%$ & $\mathbf{5 0 \%}$ & $\mathbf{5 0 \%}$ & $\mathbf{5 0 \%}$ & $\mathbf{5 0 \%}$ & $\mathbf{5 0} \%$ \\
\hline Epoch & \multicolumn{2}{|c|}{345} & \multicolumn{2}{|c|}{17} & \multicolumn{2}{|c|}{380} & \multicolumn{2}{|c|}{22} \\
\hline RMSE & 128.51329 & \begin{tabular}{|l|l|} 
& 0.340394 \\
\end{tabular} & 477.15027 & 0.556421 & 3.74402 & 0.654357 & 8.534968 & 0.621109 \\
\hline
\end{tabular}

Tabel 9 Hasil validasi ANFIS untuk aliran uap air

\begin{tabular}{|c|c|c|c|c|c|c|c|c|}
\hline \multirow{4}{*}{$\begin{array}{c}\text { ANFIS } \\
\text { Aliran } \\
\text { Uap Air }\end{array}$} & \multicolumn{8}{|c|}{ Jumlah Historical Data } \\
\hline & \multicolumn{2}{|c|}{229} & \multicolumn{2}{|c|}{500} & \multicolumn{2}{|c|}{478} & \multicolumn{2}{|c|}{800} \\
\hline & Training Data & Checking Data & Training Data & Checking Data & Training Data & Checking Data & Training Data & Checking Data \\
\hline & $90 \%$ & $10 \%$ & $90 \%$ & $10 \%$ & $\mathbf{9 0 \%}$ & $10 \%$ & $90 \%$ & $10 \%$ \\
\hline Epoch & \multicolumn{2}{|c|}{484} & \multicolumn{2}{|c|}{278} & \multicolumn{2}{|r|}{2} & \multicolumn{2}{|c|}{91} \\
\hline \multirow[t]{3}{*}{ RMSE } & 5.02969 & 18.386176 & 5.464772 & 8.505710 & 165.124442 & 54.707031 & 159.207161 & 44.385839 \\
\hline & Training Data & Checking Data & Training Data & Checking Data & Training Data & Checking Data & \begin{tabular}{|l|} 
Training Data \\
\end{tabular} & Checking Date \\
\hline & $80 \%$ & $\mathbf{2 0 \%}$ & $80 \%$ & $20 \%$ & $80 \%$ & $20 \%$ & $80 \%$ & $20 \%$ \\
\hline Epoch & \multicolumn{2}{|c|}{32} & \multicolumn{2}{|c|}{127} & \multicolumn{2}{|r|}{2} & \multicolumn{2}{|c|}{18} \\
\hline \multirow[t]{3}{*}{ RMSE } & 116.739876 & 11.638611 & 198.727315 & 8.04522 & 136.482437 & 53.047464 & 211.276671 & 37.518627 \\
\hline & Training Data & Checking Data & Training Data & Checking Data & Training Data & Checking Data & Training Data & Checking Date \\
\hline & $70 \%$ & $\mathbf{3 0 \%}$ & $70 \%$ & $30 \%$ & $70 \%$ & $\mathbf{3 0 \%}$ & $70 \%$ & $30 \%$ \\
\hline Epoch & \multicolumn{2}{|c|}{209} & \multicolumn{2}{|c|}{260} & \multicolumn{2}{|r|}{1} & \multicolumn{2}{|r|}{1} \\
\hline \multirow[t]{3}{*}{ RMSE } & 3431.591075 & 15.803392 & 4159.713336 & 12.394823 & 200.673815 & 45.962199 & 208.550079 & 39.788255 \\
\hline & Training Data & Checking Data & Training Data & Checking Data & Training Data & Checking Data & Training Data & Checking Dat: \\
\hline & $60 \%$ & $40 \%$ & $60 \%$ & $40 \%$ & $60 \%$ & $40 \%$ & $60 \%$ & $40 \%$ \\
\hline Epoch & \multicolumn{2}{|c|}{153} & \multicolumn{2}{|c|}{108} & \multicolumn{2}{|r|}{1} & \multicolumn{2}{|c|}{372} \\
\hline \multirow[t]{3}{*}{ RMSE } & 7503.541405 & 4.094257 & 14132.88263 & 2.858074 & 162.431305 & 41.083081 & 195.519736 & 26.980377 \\
\hline & Training Data & Checking Data & Training Data & Checking Data & Training Data & Checking Data & Training Data & Checking Date \\
\hline & $\mathbf{5 0 \%}$ & $\mathbf{5 0} \%$ & $\mathbf{5 0 \%}$ & $\mathbf{5 0 \%}$ & $\mathbf{5 0 \%}$ & \begin{tabular}{|l}
$\mathbf{5 0} \%$ \\
\end{tabular} & $\mathbf{5 0 \%}$ & $\mathbf{5 0} \%$ \\
\hline Epoch & \multicolumn{2}{|c|}{46} & \multicolumn{2}{|c|}{49} & \multicolumn{2}{|r|}{7} & \multicolumn{2}{|c|}{2} \\
\hline RMSE & 152.284761 & 6.23141 & 3926.65061 & 7.125512 & 179.922116 & 34.073058 & 292.302009 & 25.251285 \\
\hline
\end{tabular}


Tabel 7 menunjukan hasil validasi ANFIS untuk tekanan air. Selisih nilai terkecil antara nilai RMSE training data dengan nilai RMSE checking data untuk kesemua historical data berada pada presentase checking data sebesar 10\%, kecuali historical data ke-3 yang mana nilai tersebut berada pada presentase checking data sebesar 20\%. Nilai RMSE checking data terkecil untuk historical data ke-1 hingga historical data ke-3 berada pada presentase checking data sebesar 50\%, namun untuk historical data ke-4, nilai RMSE terkecil berada pada presentase checking data sebesar $40 \%$.

Tabel 8 menunjukan hasil validasi ANFIS untuk kualitas uap air.Selisih nilai terkecil antara nilai RMSE training data dengan nilai RMSE checking data untuk keseluruhan historical data berada pada presentase checking data sebesar 10\%. Nilai RMSE checking data terkecil untuk historical data ke-1 dan historical data ke-2 berada pada presentase checking data sebesar $30 \%$, sedangkan untuk historical data ke-3 dan historical data ke-4, nilai RMSE terkecil masing-masing berada pada presentase checking data sebesar 50\% dan $40 \%$.

Tabel 9 menunjukan hasil validasi ANFIS untuk aliran uap air. Selisih nilai terkecil antara nilai RMSE training data dengan nilai RMSE checking data untuk historical data ke-1, historical data ke-2 dan historical data ke-4 berada pada presentase checking data sebesar $10 \%$, sedangkan untuk historical data ke-3 berada pada presentase checking data sebesar $20 \%$. Nilai RMSE checking data terkecil untuk historical data ke-1 dan historical data ke-2 berada pada presentase checking data sebesar 40\%, sedangkan untuk historical data ke-3 dan historical data ke-4 berada pada presentase checking data sebesar $50 \%$.

\subsubsection{Pembahasan hasil validasi ANFIS}

Berdasarkan hasil penelitian yang telah dijelaskan pada sub sub bab sebelumnya mengenai hasil validasi masing-masing ANFIS pada setiap struktur model dengan melakukan analisis overfitting, maka didapatkan hasil parameter berupa jumlah nilai epoch. Dari hasil penelitian tersebut terdapat dua macam kemungkinan yang terjadi, yaitu nilai RMSE checking data terkecil dan selisih nilai terkecil antara nilai RMSE checking data dengan nilai RMSE training data berdasarkan variasi besar presentase untuk setiap training data dan checking data pada masing-masing historical data. Dari hasil pengamatan data untuk struktur model I dan struktur model II, historical data ke-1 dengan historical data ke-2 dan historical data ke-3 dengan historical data ke-4 memiliki kesamaan karakteristik, hal ini dibuktikan dengan keberadaan besar nilai presentase yang sebagian besar sama dalam menunjukan dua kemungkinan yang telah disebutkan sebelumnya.

Faktor yang menyebabkan masing-masing historical data memiliki kesamaan karakteristik antara satu dengan lainnya, karena dalam mendapatkan historical data ke-1 dan historical data ke-3, dilakukan penghapusan data duplikat pada historical data ke-2 dan historical data ke-3. Karakteristik lainya antara historical data ke-1 dengan historical data ke-2 dan historical data ke-3 dengan historical data ke-4 adalah dalam mendapatkan nilai RMSE checking data terkecil pada masing-masing ANFIS, secara umum historical data ke-3 dan historical data ke-4 membutuhkan presentase checking data yang lebih besar dari pada pembelajaran data menggunakan historical data ke-1 dan historical data ke-2, hal ini dikarenakan jumlah historical data ke-3 dan historical data ke-4 memiliki jumlah parameter yang lebih banyak, sehingga membutuhkan validasi data yang lebih besar untuk mencapai nilai RMSE checking data terkecil.

Berdasarkan data yang didapat, jika presentase training data semakin kecil untuk dilakukan pembelajaran dan presentase checking data semakin besar, maka secara umum tingkat kesesuaian hasil dari pemodelan tidak akurat dalam mengikuti pola data yang diberikan. Hal ini dikarenakan pola data yang dilakukan pelatihan tidak cukup untuk dapat merepresentasikan karakteristik pola data dari suatu sistem atau plant yang akan dimodelkan. Namun faktor lain yang menentukan nilai RMSE untuk training data dan checking data adalah sebaran nilai

IJEIS Vol. 5, No. 1, April 2015 : 99 - 110 
parameter plant yang dimodelkan, yang direpresentasikan dalam bentuk historical data yang digunakan dalam pembelajaran.

\subsection{Analisa Kontrol Model Prediksi}

Setelah didapatkan parameter terbaik pada masing-masing ANFIS, dengan menggunakan historical data berdasarkan presentase training data dan checking data.Kemudian dilakukan pengujian keseluruhan pada masing-masing keluaran ANFIS dari setiap struktur model. Pengujian menggunakan data masukan berupa masukan impulse sebanyak 100 data, yang diambil secara acak dari virtual mesin penghasil uap air.

Didalam melakukan pengujian kontrol model prediksi, parameter yang dijadikan acuan dalam mendapatkan parameter terbaik direpresentasikan dengan nilai RMSE pada masingmasing historical data terhadap keluaran ANFIS pada setiap struktur model.

Berdasarkan keseluruhan tabel pada analisis overfitting, hasil validasi nilai RMSE terkecil untuk setiap keluaran ANFIS ditunjukan oleh historical data ke-1 dan historical data ke-2, namun ketika dilakukan pengujian dengan data pengujian yang merepresentasikan setpoin untuk masing-masing keluaran ANFIS pada setiap struktur model didapatkan hasil berkebalikan, hal ini dikarenakan nilai RMSE training data dan nilai RMSE checking data bersifat nilai kebenaran relatif, maksudnya adalah nilai RMSE training data dan nilai RMSE checking data yang dihasilkan ketika melakukan analisis overfitting hanya berlaku pada training data dan checking data untuk pasang data saat itu.

Tabel 10 dan Tabel 11 menunjukan hasil pengujian terhadap data pengujian pada masingmasing struktur model.Blok berwarna biru menunjukan hasil validasi terbaik yang direpresentasikan dengan nilai RMSE. Dapat dilihat bahwa nilai RMSE terkecil pada setiap parameter struktur model I dan struktur model II sebagian besar dihasilkan oleh pembelajaran ANFIS dengan menggunakan historical data ke-4. Namun lain halnya untuk nilai RMSE terkecil pada parameter tekanan bahan bakar, $\mathrm{O}_{2}$ content dan kualitas uap air yang dihasilkan oleh pembelajaran ANFIS dengan menggunakan historical data ke-3. Hal ini disebabkan karena kecocokan model yang dihasilkan lebih dominan ke historical data ke-3, namun hal ini bukan merupakan masalah, karena selisih nilai RMSE pada historical data ke-3 dan historical data ke4 sangat kecil sekali, sehingga didalam implementasinya secara umum pada penelitian ini parameter terbaik yang digunakan untuk kontrol model prediksi pada mesin virtual penghasil uap air menggunakan historical data ke-4.

Tabel 10 Hasil pengujian terhadap data pengujian untuk struktur model I

\begin{tabular}{|c|c|c|c|c|c|}
\hline & & Historical data ke-1 & Historical data ke-2 & Historical data ke-3 & Historical data ke-4 \\
\hline \multirow{5}{*}{$\begin{array}{c}\mathrm{R} \\
\mathrm{M} \\
\mathrm{S} \\
\mathrm{E}\end{array}$} & Aliran Air & 6.8728 & 5.8593 & 3.2715 & 1.9941 \\
\hline & Tekanan Air & 259.5854 & 312.2136 & 57.6353 & 48.0236 \\
\hline & Aliran Udara & 4670.1301 & 5814.8437 & 1481.2406 & 604.0621 \\
\hline & Tekanan Bahan Bakar & 0.63706 & 11135 & 0.43064 & 0.7086 \\
\hline & Temperatur Bahan Bakar & 60.4664 & 66.4611 & 21.6092 & 18.6594 \\
\hline
\end{tabular}

Tabel 11 Hasil pengujian terhadap data pengujian untuk struktur model II

\begin{tabular}{|c|l|c|c|c|c|}
\hline \multicolumn{2}{|l|}{} & His trical data ke -1 & Historical data ke-2 & Historical data ke -3 & Historical data ke -4 \\
\hline \multirow{2}{*}{ R } & O2 Content & 1245.7505 & 462.1002 & 0.9333 & 0.95913 \\
\cline { 2 - 6 } M & Tekanan Uap Air & 18929.556 & 220457.72 & 78.9908 & 76.1557 \\
\cline { 2 - 6 } S & Kualitas Uap Air & 11655.442 & 3246.4125 & 3.9389 & 3.9734 \\
\cline { 2 - 6 } E & & & & \\
& Aliran Uap Air & 175309.79 & 121278.62 & 273.5649 & 264.9173 \\
\hline
\end{tabular}




\section{KESIMPULAN}

Berdasarkan penelitian yang telah dilakukan, dapat diambil kesimpulan sebagai berikut:

- Telah diimplementasikan Adaptive Neuro Fuzzy Inference System (ANFIS) sebagai unit peyusun model dari kontrol model prediksi pada mesin virtual penghasil uap air.

- Didapatkan parameter terbaik untuk masing-masing ANFIS pada setiap struktur model yang diimplementasikan pada mesin virtual penghasil uap air, dengan parameter sebagai berikut:

a. Data pelatihan dalam melakukan pembelajaran ANFIS menggunakan historical data ke-4 yang berjumlah 800 data.

b. Rasio presentase pembelajaran untuk training data dan checking data pada masing-masing ANFIS untuk setiap struktur model secara berurutan sebesar $90 \%$ dan $10 \%$, kecuali rasio presentase untuk ANFIS pada parameter aliran air secara berurutan sebesar $80 \%$ dan $20 \%$.

- Hasil validasi RMSE (Root Mean Square Error) dengan melakukan pengujian terhadap 100 data, didapatkan nilai sebagai berikut: aliran air=1.9941, tekanan air $=48.0236$, aliran udara $=604.0621$, tekanan bahan bakar $=0.7087$, temperature bahan bakar $=18.6594, \mathrm{O}_{2}$ content $=0.9591$, tekanan uap air=76.1557, kualitas uap air=3.9734 dan aliran uap air=264.9173.

\section{SARAN}

Dibutuhkan historical data yang lebih banyak dengan variasi yang lebih variatif untuk masing-masing ANFIS pada setiap struktur model, sehingga tingkat validasi ANFIS akan semakin tinggi, yang akan berpengaruh terhadap kemampuan dari kontrol model prediksi.

\section{DAFTAR PUSTAKA}

[1] Buragohain, M. dan Mahanta, C., 2006. ANFIS Modelling of Nonlinear System Based on Vfold Technique. Departement of ECE, Indian Institute of Technology Guwahati, Guwahati, Assam.

[2] Halvorsen, H., 2011. Model Predictive in LabVIEW.Departement of Electrical Engineering, Information Technology and Cybernetics, Telemark University College.

[3] Sivakumar, R. dan Balu, K., 2010. ANFIS Based Destillation Column Control. Departement of Electronics and Instrumentation, St. Joseph's College, India.

[4] Kuniawan, R., 2012. Laporan Kerja Praktek, Analisa Kinerja Steam Generator Menggunakan Artificial Intelligence. PT. Chevron Pacific Indonesia, Duri. 